\title{
DOCEAMUS
}

doceamus...let us teach

\section{Listening to Teachers}

\section{Priscilla Bremser}

In the first Doceamus column [12], Herbert Wilf wrote, "Our quality of education will improve when we have more teachers who are knowledgeable in their subject and who enjoy doing it and talking about it." A year later, Solomon Garfunkel's “The Common Core Standards-Educational reform and us" [4] mentions teachers in just one paragraph. Ten months after that, Irwin Kra offered "(Math) Teachers are the key" [5]. Absent from any of those columns are the voices of teachers themselves. While it is gratifying to see mathematicians paying close attention to $\mathrm{K}-12$ education, we will be better able to contribute constructively to that enterprise if we simply listen to teachers now and then.

Last summer, Ms. K. mentioned that she would be teaching fourth grade in the fall, but prefers middle school students, a cohort that would challenge many of us. I'm still amazed by the volatile energy my sons and their friends presented at that age. As it turns out, though, that abundant adolescent energy is the attraction for Ms. K.; she finds it invigorating. For another teacher, "This is our last chance to get the math right before high school." A third says, "What these kids are thinking is closer to the surface. They're more willing to show enthusiasm." This brings me years back to my twins' eighth-grade classroom. During an enrichment activity I was leading before school, a boy blurted out, "Oh! That's a parabola! I love parabolas!" Not one of my college students has ever said that.

Priscilla Bremser is professor of mathematics at Middlebury College. Her email address is bremser@mi dd 1 ebury. edu.

Members of the Editorial Board for Doceamus are: David Bressoud, Roger Howe, Karen King, William McCallum, and Mark Saul.

DOI: http://dx.doi.org/10.1090/noti1107
My point is not to convert mathematicians into middle-school educators, but rather to suggest that teachers' stories can challenge our assumptions about mathematics education and how it might be improved. We've all heard conjectures, stated as facts, from colleagues concerning how arithmetic is taught, why some of our students can't do algebra, and so on; I've made a few myself. As we consider test scores [8], [11] and critiques of testing [7], [10], follow the implementation of the Common Core State Standards [2], and scan recent work [3] on how children learn mathematics, we can round out our understanding by hearing directly from people doing the real work. It is anecdotal information, so we need to use it carefully. But it might keep us from rushing to judgment. At the very least it can help shape the questions we ask.

For example, a seventh-grade teacher plans his lessons with the high school curriculum in mind. It's a small middle school, and in one class he has kids bouncing out of their seats with enthusiasm for repeating decimals alongside two who are functioning at a second-grade level and trying not to get noticed. Is there anything in this teacher's training or professional development that could support his efforts to reach all of his students? Is there time in his day to consult with colleagues? Does his principal understand the mathematics well enough to recognize the challenge he faces? (Not necessarily, I've learned.)

The usual setting for my conversations with teachers is the Vermont Mathematics Initiative, a master's program at the University of Vermont for practicing teachers. I have been a VMI instructor since 2007, including three summer sessions in the Cincinnati offshoot. But one doesn't need a formal commitment to engage in meaningful discussions 
with K-12 educators. ${ }^{1}$ I have stayed in touch with former students teaching mathematics in public, charter, and private schools in the U.S. and in the Peace Corps. I also give math talks in Vermont schools, which sometimes includes lunch (if only for 32 minutes) with teachers. Provocative stories grow out of seemingly ordinary exchanges.

In a school district far from Vermont, teachers have strict guidelines that specify weekly content, and students take standardized tests each month. One Friday, a teacher was confident that she had completed that month's material, and took the time to go back to a previous topic that had been rushed. The "Math Coach" visiting her class that day went directly to the principal and reported the teacher for deviating from procedure. I fervently hope that this story is not typical, but it does serve as a reminder that public school teachers have far less autonomy than I do. There are natural reasons for that, of course, but surely some decisions are better left to teachers. What would an appropriate level of teacher autonomy look like?

Closer to home, a kindergarten teacher near the Canadian border has some entering students who cannot count. They reel off numbers, but they have no sense of order. This story gets filed in the "Reality Check" folder; when we say we have clear expectations for teachers, are those expectations reasonable in context? Also in this file is a middle-school teacher in a crumbling Southern city. During parent-teacher conferences, parents nod and smile and promise to reinforce the homework agreement and get their kids to school on time, but there's often no follow-through; a few parents actually enable truancy. How can teachers form productive partnerships with parents whose own school experiences were largely negative?

Early one June morning in Cincinnati, two teachers are discussing the death of a student in an isolated low-income neighborhood. A few months later, it's hunting season in Vermont, and one high school has an honor roll of sorts in the front hall, listing students' deer kills. A few of their families rely on that venison in the freezer to get through the winter. When we compare our kids to those in Finland and Canada, countries with lower Gini indices than ours, how do we tease out the strong correlation between family income and performance on standardized tests [6]? Can we realistically expect to improve educational outcomes, in mathematics or any other area, for all children without addressing poverty in the United States?

Then there's the "Omnes Docemus"-“We All Teach"-folder. Some stories capture the joy of watching a student catch on to a new idea, be

\footnotetext{
${ }^{1}$ For an account of extreme commitment, see [13].
}

it subtraction or quotient groups. Others note the infiltration into our classrooms of a stubborn cultural resistance to the very subject we teach. We who teach mathematics also share a constant tension between the breadth of material we expect to cover and the depth to which we want our students to understand it. Can mathematicians who choose active involvement in schools build on such commonalities? ${ }^{2}$

Not so fast, you say-there are differences between schoolteachers and college professors. For one thing, we know more mathematics than they do. This is true, and teachers know that it's true; sadly, their discomfort can get in the way of a good conversation. Fortunately for me, the VMI environment entails substantive mathematical discourse with teachers. While I'm in their company, though, I also want to hear about the things they know better. What do you do on the first day with Somali teenagers who know only basic arithmetic and no English? How do you keep an immature but mathematically brilliant fourth-grader engaged? What techniques have you found for channeling that middle-school energy toward mathematics?

Herbert Wilf and Irwin Kra bring our attention to a crucial issue; a student's teacher is the single in-school variable with the most influence on learning [9]. ${ }^{3}$ Kra's conclusion: "To put good math teachers in the classroom, society must expect more from them, must pay them more, and must give them the support and respect they deserve." Agreed. But as we devise strategies to do so, we would do well to listen to the ones who are already there. We'll get a more detailed picture of why current and future teachers deserve our respect, and more focused proposals for supporting them.

\section{References}

[1] Sybilla BeckmanN, The community of math teachers, from elementary school to graduate school, Notices of the American Mathematical Society 58 (2011), 368-371.

[2] Common Core State Standards for Mathematics, www. corestandards.org/.

[3] M. SUZANNE DONOVAN and JOHN D. BRANSFORD, editors, How Students Learn: Mathematics in the Classroom, The National Academies Press (2005).

[4] Solomon Garfunkel, The Common Core State Standards-Education reform and us, Notices of the American Mathematical Society 58 (2011), 820-821.

[5] IRwIN KRA, (Math) Teachers are the key, Notices of the American Mathematical Society 59 (2012), 556-557.

[6] H. F. LADD, Education and poverty: Confronting the evidence, presidential address to the Association for Public Policy Analysis and Management, Journal of Policy Analysis and Management 31.2 (2012), 203-227.

\footnotetext{
${ }^{2}$ Sybilla Beckman [1] makes a strong case for the affirmative.

${ }^{3}$ Research indicates, however, that out-of-school factors are more influential than in-school ones. See, for example, [9].
} 
MAthematics at the National Security Agency

\section{Rise Above the Ordinary}
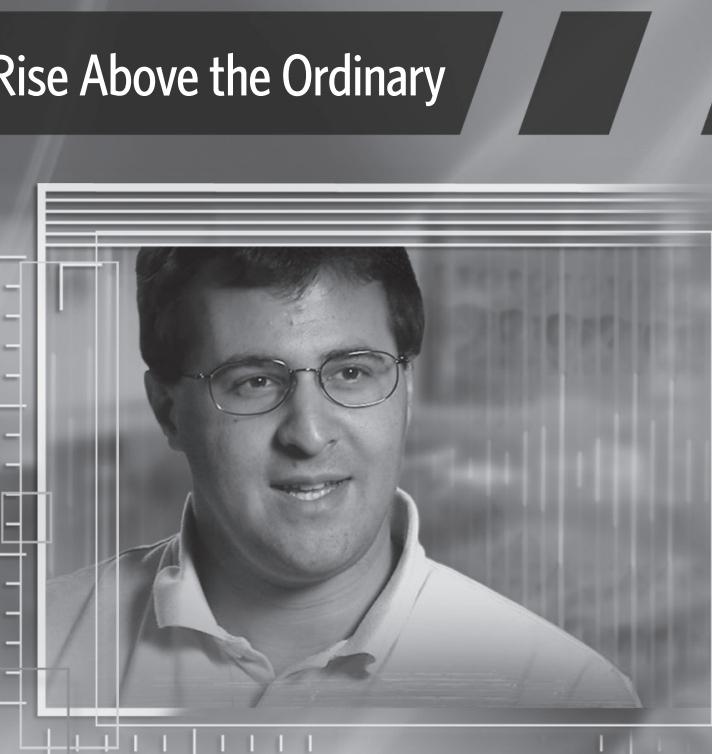

A career at NSA is no ordinary job. It's a profession dedicated to identifying and defending against threats to our nation. It's a dynamic career filled with challenging and highly rewarding work that you can't do anywhere else but NSA.

You, too, can rise above the ordinary. Whether it's producing valuable foreign intelligence or preventing foreign adversaries from accessing sensitive or classified national security information, you can help protect the nation by putting your intelligence to work.

NSA offers a variety of career fields, paid internships, co-op and scholarship opportunities.

Learn more about NSA and how your career can make a difference for us all.

\section{KNOWINGMATTERS}

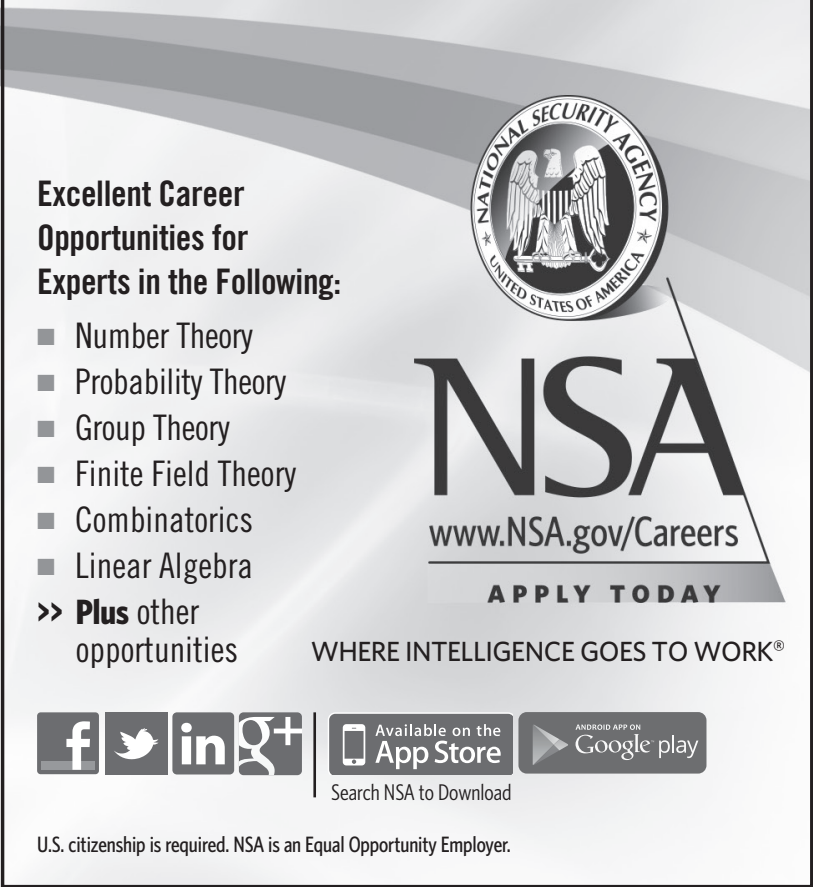

[7] SANDRA MATHISON and E. WAYNE Ross, editors, The Nature and Limits of Standards-Based Reform and Assessment, Teachers College Press, 2008.

[8] National Assessment of Educational Progress, nces.ed.gov/nationsreportcard/.

[9] Teachers Matter: Attracting, Developing, and Retaining Effective Teachers, Organisation for Economic Co-operation and Development, 2005.

[10] AlAN H. SCHOENFELD, editor, Assessing Mathematical Proficiency, Mathematical Sciences Research Institute, 2007.

[11] Trends in International Mathematics and Science Study, http://nces.ed.gov/timss/

[12] HERBERT S. WILF, On buckets and fires, Notices of the American Mathematical Society 57 (2010), 750-751.

[13] DARRYL YONG, Adventures in teaching: A professor goes to high school to learn about teaching math, Notices of the American Mathematical Society 59, 1408-1415. 